Shuquan Li, Meng Fan \& Xiuyu Wu (2019). "Lean Construction Techniques and Individual Performance." In: Proc. 27 $7^{\text {th }}$ Annual Conference of the International. Group for Lean Construction (IGLC), Pasquire C. and Hamzeh F.R. (ed.), Dublin, Ireland, pp. 1469-1478. DOI: https://doi.org/10.24928/2019/0136. Available at: <www.iglc.net>.

\title{
LEAN CONSTRUCTION TECHNIQUES AND INDIVIDUAL PERFORMANCE
}

\author{
Shuquan Li ${ }^{1}$ Meng Fan ${ }^{2}$ Xiuyu $\mathrm{Wu}^{3}$
}

\begin{abstract}
The adoption of lean construction techniques in construction industry can eliminate waste and increase profit, and this paper is to test the maturity of implementation of lean construction tools in construction project, as well as the impact of lean construction tools on individual performance. In this research, five widely used lean construction techniques were selected (Last Planner system (LPS), visualization tool, six step plan(6S), Just-in-time (JIT) and Total quality management (TQM)), and individual performance was divided into two dimensions: task performance and contextual performance. The data collection methods included interviews and questionnaires, and the data analyzed via SPSS software. The results showed that the highest maturity implementation of lean construction tools in the investigated projects was TQM, had positive impact on individual performance, while LPS was the lowest maturity tool and had least impact on individual performance; for task performance, $6 \mathrm{~S}$ was the most effective technique, and for contextual performance, the most effective tool was visualization tool. This study provides theoretical support and guidance for construction enterprises to select lean construction techniques to improve individual performance.
\end{abstract}

\section{KEYWORDS}

Lean construction, individual performance, maturity, technique, implementation

\section{INTRODUCTION}

As the mainstay industry of Chinese national economy, construction industry brings great wealth to the society. At the same time, a series of problems has exposed with the continuous expansion of the construction market. Research has shown that 25\% 30\% of the construction process in the traditional construction industry is to rework, which lead to $30 \% \sim 60 \%$ waste of labor force, as well as the $10 \%$ waste of material, up to

1 Professor, Department of Management Science and Engineering, School of Management Science and Engineering, Tianjin University of Finance and Economics, 25 Zhujiang Rd, Hexi District, TianJin, China. E-mail: 1sq200612@,126.com

2 Ph.D. Student, Department of Management Science and Engineering, School of Management Science and Engineering, Tianjin University of Finance and Economics, 25 Zhujiang Rd, Hexi District, TianJin, China (corresponding author). E-mail: fanmeng_0425@163.com

3 Lecture, Department of Management Science and Engineering, School of Management Science and Engineering, Tianjin University of Finance and Economics, 25 Zhujiang Rd, Hexi District, TianJin, China. E-mail: xywu2014@126.com 
$10 \% \sim 20 \%$ of the total project cost. Therefore, in order to achieve sustainable development and green development of construction industry, it is necessary to reduce the building energy consumption and minimize the waste of material, time or labor force. Numerous approaches have been developed to reduce waste and improve efficiency of construction processes, and Lean Construction(LC) as a new philosophy based on lean manufacturing concepts (Koskela, 1992), with its focus on the reduction and elimination of the waste, offer the promise to minimize non value-adding work. In addition, research has indicated that the implementation of LC had benefits associated with sustainable construction; the contribution of LC techniques in sustainable construction cannot be over emphasized.

The study of LC beginning in the early 1990s, had made achievement in countries like UK (Mossman, 2009), Singapore (Dulaimi and Tanamas, 2001), Brazil (Silva and Cardoso, 1999), USA (Nahmens and Ikuma, 2009), and so on. At the beginning of 21st century, the Chinese scholars also explore the implementation of lean philosophy in the construction industry. Current research about application of LC mainly focuses on the following two aspects: one is the implementation of LC techniques, including applicability, influencing factors, implementation path, and so on; the other is the performance research of LC implementation. There are still a lot of manual work in the implementation of LC; the overall performance of the project comes from the individual performance set in the production process. The existing research about lean philosophy mainly focused on the research of project performance but ignore the importance of individual performance, hence, this paper research the impact of LC techniques on individual performance, provides theoretical support for company to choose suitable LC techniques in order to improve individual performance and project performance.

\section{THEORETICAL BASIS AND HYPOTHESIS}

\section{LEAN CONSTRUCTION}

Lean construction was pioneered by Koskela (1992), who developed the transformation flow view (TFV) theory of production in construction, and introduced the idea of understanding construction as production (Ogunbiyi et.al, 2014; Salem et.al, 2005). LC was described as a way to design production systems to minimize waste of materials, time, and workforce, in order to generate the maximum possible amount of value (Koskela, 2002). The Construction Industry Institute (CII) has defined LC as "the continuous process of eliminating waste, meeting or exceeding all customer requirements, focusing on the entire value stream, and pursuing perfection in the execution of a constructed project". LC visualizes the project as a flow of activities that must generate value to the customer. According to Koskela(1992) and Thomas et al.(2002), the core concepts of LC is just-in-time (JIT), which use pull-driven scheduling to reduce the variability in process and waste, units should be available only when required. Three methods are associated with JIT: kanban system, production level, and decrease the number of setup activities (Chaoiya et al. 2000; Miltenburg, 2002; Salem et al., 2006). The concept of last planner proposed by Ballard is a technique based on lean think to minimize the waste in a system through assignment-level 
planning or detailed look-ahead scheduling. The "last planner" refers to the last individual, typically the subcontractor superintendent or foreman, who best understand their abilities to complete their respective work with a determined time duration, providing more accurate input on the construction schedule (Fernandez-Solis et al., 2013; Kongguo,2014).

Besides these two tools, other three LC tools are chosed in this paper to evaluate visualization tools, six-step plan (6S), and total quality management (TQM). Visualization lean tool is about communicating key information effectively to the workforce through posting various signs and labels around the construction site. Works can remember elements such as workflow, performance targets, and specific required actions through the visualization tools (Moser and Dos santos, 2003; Salem et al., 2005). $6 \mathrm{~S}$ helps to eliminate wasteful resources to create an organized and facility environment with six steps (Hirano, 1996): Seiri (straighten up), seiton (put things in order), seiso (clean up), seiketsu (personal neatness), shitsuke (discipline) and safety. TMQ is the quality management at every stage of operation, from planning and design through selfinsection, to continual process monitoring for improvement opportunities (Radnor, 2000).

In the next parts the maturity of the implementation of these five LC techniques (LPS, JIT, 6S, Visualization tool and TQM) are evaluated, and the relationship between the implementation of LC techniques and individual performance are investigated.

\section{INDIVIDUAL PERFORMANCE}

Performance is behavior with an evaluative component, behavior that can be evaluated as positive or negative for individual or organizational effectiveness (Motowidlo et al., 1997). It has proven that individual performance involves not only task performance, but also contextual performance, which was first proposed by Borman and Motowidlo (1993). Task performance behaviors are associated with the use of technical skills and job-specific knowledge that provide indirect support for the organization's core technical processes. When employees use technical skills and knowledge to accomplish a task, they are engaging in task performance. In contrast, contextual performance behaviors are associated with interactions with coworkers, supervisors, or customers, that support the organizational, psychological and social context in which task activities are performed. When employees help others complete a task, cooperate with their supervisors, or suggest ways to improve organizational processes, they are engaging in contextual performance (Scotter et al., 2000; Edwards, et al., 2008; Muhammad, et al. 2016). The two dimensions of individual performance had been widely accepted by researchers, and in this paper the author choose task performance and contextual performance as the measurement of individual performance.

\section{HYPOTHESIS}

The research about the implementation of LC techniques mainly focus on the reduction of waste, improvement of efficiency and workflow, project performance and so on. Luis et al. (2008) spend five years to evaluate the LC implementation in more than 100 construction projects in Chile, the result showed that different implementation levels of 
LPS impact the improvement of project. The LPS was also found can improve the flow of the finishing stage by assigning the tasks in sufficient detail and modeling the production units (Murguía et al., 2016). Concha et al. (2015) proved that lean principles and concepts could positive impact the cost, time, variability and waste reduction in organizations. Beside this, as the important position of LC tools to deal with the issues of wastes in projects, LC implementation has been discussed as the robust approach for project management (Ansah et al., 2016). Zhang and Chen (2016) talked about the knowledge management of LC and the results showed that lean tools have a positive effect on knowledge creation and finally promote lean performance. There are few studies about the implementation of LC techniques and individual performance, while contextual performance makes an important contribution to organizational effectiveness (Borman and Motowidlo, 1993). Therefore, the following hypothesis are proposed:

H1: PLS is positively associated with individual performance;

$\mathrm{H} 2$ : JIT is positively associated with individual performance;

$\mathrm{H} 3$ :TQM is positively associated with individual performance;

H4: 6S was positively associated with individual performance;

H5: Visualization is positively associated with individual performance.

\section{METHODOLOGY}

\section{DATA COLLECTION}

Data were collected through respondents from China construction workers via questionnaires. The contents of the questionnaire include the basic information of projects, the maturity level of implementation of LC techniques, the level of individual performance, and personal information. The questionnaire was rated on 5-point Likert scale with strongly disagree to strongly agree at points 1-5, respectively. The distribution way including e-mail, mailing and on-site distribution. A total of 770 questionnaires were sent out and 710 questionnaires were completed and returned. Invalid questionnaires were removed according to the three criterions: 1) the number of missing items exceeds $10 \%$ of the total items; 2) the answers of all items in the questionnaire are regular, such as the same answer for all items or repeated answers regularly; 3) two or more answers in the multiple choice question, 667 valid questionnaires were obtained, and the usable response rate was $86.6 \%$.

Among the valid samples, the investigated projects were distributed in 18 provinces, most located in North China and East China. The main types of projects are civil engineering, accounting for $57.7 \%$ of the total, and the main structure type is frame structure, accounting for $53.4 \%$ of the total. Among the 667 construction workers investigated, $93.4 \%$ were male and $6.6 \%$ were female. In terms of age distribution, most of the respondents were under 40 years old, especially those aged 31 to 40 , accounting for $43.1 \%$ of the total. In terms of educational level, the number of people with less than junior college degree accounts for $66.8 \%$ of the total number, and the proportion of those with college degree or above is $33.2 \%$. For the distribution of management 
levels, grass-roots managers and professional and technical personnel are relatively concentrated, accounting for $83.2 \%$ of the total personnel, followed by the proportion of middle-level managers of the company is $14.1 \%$, and finally the proportion of senior managers is $2.7 \%$. The result is in line with reality.

\section{RELIABILITY AND VALIDITY ANALYSIS}

Firstly, the reliability and validity of the questionnaire were analyzed by SPSS software, the commonly used reliability test index is the Cronbach's Alpha coefficient. The closer the coefficient is to 1 , the better the reliability and stability of the questionnaire is. As shown in Table 1, the Cronbach's Alpha values of LC technique and individual performance are 0.875 and 0.803 , and the Standardized Cronbach's Alpha values are 0.877 and 0.823 , respectively. The results indicate that the scale has high internal consistency and high reliability.

Table 1: Reliability statistics

\begin{tabular}{cccc}
\hline Constructs & $\begin{array}{c}\text { Cronbach's } \\
\text { Alpha }\end{array}$ & $\begin{array}{c}\text { Standardized } \\
\text { Cronbach's Alpha }\end{array}$ & items \\
\hline LC Techniques & .875 & .877 & 26 \\
Individual performance & .803 & .823 & 14 \\
\hline
\end{tabular}

Validity test is a test of the accuracy or validity of the items in the questionnaire. The Kaiser-Meyer-Olkin (KMO) coefficient and the Bartlett sphericity test are generally used as the measurement indexes. As shown in Table 2, the KMO values of LC techniques and individual performance were 0.894 and 0.862 , respectively, and the sig. $=0.000<0.005$, indicated that the validity of the scale was better.

Table 2: Test of KMO and Bartlett

\begin{tabular}{lrrr}
\hline Constructs & & LC Techniques & Individual \\
\hline KMO & & .894 & .862 \\
Bartlett & $\chi^{2} ;$ & 4834.317 & 2523.844 \\
& $\chi^{2} / d f ;$ & 325 & 91 \\
& Sig. & .000 & .000 \\
\hline
\end{tabular}

\section{HYPOTHESIS TEST AND DISCUSSION}

\section{HYPOTHESIS TEST}

Firstly, the maturity level of the implementation of LC techniques were evaluated by the average score of each item. The results showed that the highest maturity level is TQM, followed by visualization tools, 6S and JIT, while LPS had the lowest maturity.

Table 3: Maturity level of the implementation of LC techniques 


\begin{tabular}{|c|c|c|c|c|c|c|c|c|c|}
\hline LPS & & Visualization & & $6 S$ & & JIT & & TQM & \\
\hline $\begin{array}{l}\text { Daily work } \\
\text { plan }\end{array}$ & 3.59 & PPC charts & 4.10 & Seiri & 3.86 & $\begin{array}{l}\text { Workflow linked } \\
\text { closely }\end{array}$ & 3.73 & $\begin{array}{l}\text { PDCA } \\
\text { techniques }\end{array}$ & 3.56 \\
\hline $\begin{array}{l}\text { Weekly work } \\
\text { plan }\end{array}$ & 3.94 & $\begin{array}{l}\text { Project } \\
\text { schedule }\end{array}$ & 4.17 & Seiton & 3.94 & $\begin{array}{l}\text { Mariterial and } \\
\text { equipment arrived } \\
\text { on time }\end{array}$ & 3.85 & $\begin{array}{l}\text { Total staff } \\
\text { take part in } \\
\text { quality control }\end{array}$ & 4.07 \\
\hline $\begin{array}{l}\text { Commitment } \\
\text { plan }\end{array}$ & 3.48 & $\begin{array}{l}\text { Work } \\
\text { standard }\end{array}$ & 3.91 & Seiso & 3.89 & $\begin{array}{l}\text { Standardization of } \\
\text { workflow }\end{array}$ & 3.97 & $\begin{array}{l}\text { Whole process } \\
\text { of quality } \\
\text { control }\end{array}$ & 4.24 \\
\hline $\begin{array}{l}\text { Look-ahead } \\
\text { schedule }\end{array}$ & 3.9 & & & Seiketsu & 4.08 & $\begin{array}{l}\text { Workload is } \\
\text { similar in each } \\
\text { section }\end{array}$ & 4.02 & $\begin{array}{l}\text { Cost } \\
\text { accounting }\end{array}$ & 4.3 \\
\hline \multirow[t]{2}{*}{ Learn } & 4.02 & & & Shitsuke & 4.01 & $\begin{array}{l}\text { Component } \\
\text { prefabrication }\end{array}$ & 3.67 & $\begin{array}{l}\text { Eliminate } \\
\text { equipment } \\
\text { failure }\end{array}$ & 4.09 \\
\hline & & & & Safety & 4.13 & & & $\begin{array}{l}\text { Maintain well } \\
\text { cooperation }\end{array}$ & 4.08 \\
\hline Average & 3.80 & Average & 4.01 & Average & 3.99 & Average & 3.85 & Average & 4.06 \\
\hline
\end{tabular}

The relationship between LC and individual performance was analyzed via the bivariate correlation analysis in SPSS software. The correlation coefficient of Pearson is used to express the relationship between variables. As shown in Table 4, there is a significant positive correlation between LC techniques and task performance (LPS:0.383, visualization: 0.394, 6S: 0.464, JIT:0.438, TQM: 0.452; p < 0.01).There was a significant positive correlation between LC techniques and contextual performance (LPS:0.377, visualization: 0.470, 6S: 0.388, JIT: 0.435, TQM: 0.436; p < 0. 01), which indicated that the H1 H5 were accepted. In terms of task performance, the correlation ranking of LC technique is 6S, TQM, JIT, visualization and LPS; for contextual performance, the ranking is Visualization, TQM, JIT, 6S and LPS.

Table 4: Pearson correlation coefficient between LC techniques and individual performance

\begin{tabular}{cccccccc}
\hline & LPS & visualization & $6 S$ & JIT & TQM & $\begin{array}{c}\text { Task } \\
\text { performance }\end{array}$ & $\begin{array}{c}\text { Contextual } \\
\text { performance }\end{array}$ \\
\hline LPS & 1 & & & & & & \\
Visualization & $0.581^{* *}$ & 1 & & & & & \\
\hline
\end{tabular}




\begin{tabular}{cccccccc}
\hline 6S & $0.480^{* *}$ & $0.464^{* *}$ & 1 & & & & \\
JIT & $0.543^{* *}$ & $0.503^{* *}$ & $0.530^{* *}$ & 1 & & & \\
TQM & $0.511^{* *}$ & $0.490^{* *}$ & $0.568^{* *}$ & $0.571^{* *}$ & 1 & & \\
$\begin{array}{c}\text { Task } \\
\text { performance }\end{array}$ & $0.383^{* *}$ & $0.394^{* *}$ & $0.464^{* *}$ & $0.438^{* *}$ & $0.452^{* *}$ & 1 & \\
$\begin{array}{c}\text { Contextual } \\
\text { performance }\end{array}$ & $0.377^{* *}$ & $0.470^{* *}$ & $0.388^{* *}$ & $0.435^{* *}$ & $0.436^{* *}$ & $0.674^{* *}$ & 1 \\
\hline $\begin{array}{c}* * * \\
\text { p }<.01 \text { (two-tailed set) }\end{array}$ & & & & & & 1 \\
\hline
\end{tabular}

\section{DISCUSSION}

The highest maturity of the implementation of LC technique is TQM (4.06), followed by visualization (4.01), 6S (3.99), JIT (3.85), while LPS (3.80) has the lowest maturity. TQM is a LC technique that related to project cost and quality, it has higher maturity in project indicates that cost control and quality management have become the focus of construction company. The tools of visualization and $6 \mathrm{~S}$ are the comprehensive LC techniques which complex cost, quality and schedule of the project, have widely used in construction company because of its strongly operability. The tools of JIT and LPS are the LC techniques concerned with the project schedule. Take account of the actual situation of the construction project, the duration of the project is affected by many uncertain factors. Therefore, the implementation of LC techniques related to project schedule has lower maturity level.

The correlation coefficient between LC and individual performance indicates that, LC has a positive impact on individual performance. In terms of task performance, the most effective LC technique is $6 \mathrm{~S}$, which means that promoting the implementation of 6S has the most obvious impact on job-related behaviors. For the contextual performance, the most effective LC technique is visualization tools, that means, improving the visualization of project site can promote psychological and social context. Combined with the maturity of implementation of LC techniques, TQM has the highest maturity and has the greatest impact on individual performance, while LPS has the lowest maturity and has the least impact on individual performance. Therefore, it can be concluded that the maturity level of LC techniques has relationship to the individual performance; Different LC technique has different impact on task and contextual performance. The supervisors should choose suitable LC tools to improve individual performance, instead of implementing blind.

\section{CONCLUSION}

In this paper, five LC techniques were selected to investigate, including the maturity of implementation, and the relationship between LC techniques and individual performance. The data were obtained by questionnaires and analyzed by SPSS software. The research showed that LC techniques could positively promote the two dimensions of individual performance, and the maturity level of implementation of LC techniques affects the effect degree of LC implementation of individual performance. The results 
provide theoretical support for the selection of appropriate LC techniques for construction company.

\section{ACKNOWLEDGEMENT}

This research was supported by the National Natural Science Foundation of China (Grant number 71171140)

\section{References}

Ansah, R. H., Sorooshian, S., \& Mustafa, S. B. (2016). "Lean construction: an effective approach for project management". ARPN Journal of Engineering and Applied Sciences, 11(3), 1607-1612.

Borman, W. C., \& Motowidlo, S. M. (1993). "Expanding the criterion domain to include elements of contextual performance". Personnel Selection in Organizations; San Francisco: Jossey-Bass, 71.

Chaoiya, C., Liberopoulos, G., and Dallery, Y. (2000). "The extended kanban control system for production coordination of assembly manufacturing systems." IIE Trans., 32, 999-1012.

Concha M. , Alarcón L.F., Mourgues C. \& Salvatierra J.L.(2015). “Using organizational modeling to assess the impact of lean construction principles on project performance". International group for lean construction. July 29-31:711-721

Dulaimi, M. F., \& Tanamas, C. (2001). "The principles and applications of lean construction in Singapore". 9th International Group for Lean Construction.

Edwards, B. D., Bell, S. T., Arthur, Jr, W., \& Decuir, A. D. (2008). "Relationships between facets of job satisfaction and task and contextual performance". Applied psychology, 57(3), 441-465.

Fernandez-Solis, J. L., Porwal, V., Lavy, S., Shafaat, A., Rybkowski, Z. K., Son, K., \&

Radnor, Z. (2000). "Changing to a lean organisation: the case of a chemicals company". International Journal of Manufacturing Technology and Management, 1(4-5), 444-454.

Hirano, H. (1996). 5S for operators: 5 pillars of the visual workplace. Productivity press.

Kongguo, Z. (2014). "Research on the emergence mechanism of Last Planner System of lean construction". In The 26th Chinese Control and Decision Conference (2014 CCDC) (pp. 3643-3646). IEEE

Koskela, L. (1992), “Application of the new production philosophy to construction”, Technical Report No. 72, Department of Civil Engineering, Center for Integrated Facility Engineering, Stanford University, Stanford, CA.

Koskela, L. (2002). "The theory of project management: Explanation to novel methods." Proc., Int. Group for Lean Construction 10th Annual Conf. (IGLC-10), IGLC, Gramado, Brazil, (http:// www.cpgec.ufrgs.br/norie/iglc10/papers/index.htm) (May $15,2004)$

Lagoo, N. (2012). "Survey of motivations, benefits, and implementation challenges of 
last planner system users". Journal of construction engineering and management, 139(4), 354-360.

Miltenburg, J. (2002). "Balancing and scheduling mixed-model U-shaped production lines.” Int. J. Flexible Manufacturing Systems, 14, 119-151.

Mossman, A. (2009), "Why is not the UK construction industry going lean with Gusto?". Lean Construction Journal, 5 (1). 24-36.

Moser, L., \& Dos Santos, A. (2003, July). "Exploring the role of visual controls on mobile cell manufacturing: a case study on drywall technology". In Proceedings of the 11th Annual Conference of the International Group for Lean Construction (IGLC).

Motowildo, S. J., Borman, W. C., \& Schmit, M. J. (1997). "A theory of individual differences in task and contextual performance". Human performance, 10(2), 71-83.

Murguía, D., Brioso, X., \& Pimentel, A. (2016). “Applying lean techniques to improve performance in the finishing phase of a residential building". In 24th Annual Conference of the International Group for Lean Construction (43-52). IGLC Boston, Ma, USA.

Nahmens, I. and Ikuma, L.H. (2009), “An empirical examination of the relationship between lean construction and safety in the industrialized housing industry", Lean Construction Journal, 1-12.

Ogunbiyi, O., Goulding, J. S., \& Oladapo, A. (2014). “An empirical study of the impact of lean construction techniques on sustainable construction in the UK”. Construction innovation, 14(1), 88-107.

Salem, O., Solomon, J., Genaidy, A. and Luegring, M. (2005), "Site Implementation and assessment of lean construction techniques", Lean Construction Journal, 2(2), 88-107

Salem O., Solomon J.; Genaidy A.\& Minkarah I.(2006). "Lean Construction: From Theory to Implementation". J. Management in Engineering Octorber .168-175

Silva, F.B. and Cardoso, F.F. (1999), "Applicability of logistics management in lean construction: a case study approach in Brazilian building companies", Proceedings IGLC-7, University of California, Berkeley, CA.

Thomas, H. R., Horman, M. J., De Souza, U. E. L., \& Zavřski, I. (2002). "Reducing variability to improve performance as a lean construction principle". Journal of Construction Engineering and management, 128(2), 144-154.

Tufail, M. S., Muneer, S., \& Ishtiaq, M. (2016). "Job Characteristics with Task and Contextual Performance: Moderating Role of Procedural Justice for Front Line Managers". Journal of Social Sciences. AIC 2016.499-508

Van Scotter, J., Motowidlo, S. J., \& Cross, T. C. (2000). "Effects of task performance and contextual performance on systemic rewards". Journal of applied psychology, 85(4), 526-535.

Zhang, L., \& Chen, X. (2016). "Role of lean tools in supporting knowledge creation and performance in lean construction”. Procedia Engineering, 145, 1267-1274. 
